\title{
Positive Youth Religious and Spiritual Development: What We Have Learned from Religious Families
}

\author{
David C. Dollahite *(1) and Loren D. Marks $\mathbb{D}$ \\ School of Family Life, Brigham Young University, Provo, UT 84602, USA; loren_marks@byu.edu \\ * Correspondence: david_dollahite@byu.edu
}

Received: 5 August 2019; Accepted: 20 September 2019; Published: 25 September 2019

\begin{abstract}
In this article, we highlight the contributions of the findings from a branch of the American Families of Faith national research project that pertain to positive religious and spiritual development in youth. We present detailed findings from six previous studies on religious youth and their parents from diverse faith communities (various denominations in Christianity, three major branches of Judaism, and two major groups in Islam). We discuss what our findings suggest for positive religious/spiritual development, particularly in a family context. Finally, we suggest several ways to strengthen the literature on development in youth by exploring positive religious/spiritual development in relation to (a) social and political activism, (b) popular media and music, (c) participation in secular activities (e.g., sports, arts, gaming), (d) wrestling with BIG questions (i.e., questions involving Being, Intimacy, and God), (e) conversion and disaffiliation, (f) interfaith knowledge and experience, (g) impactful personal experiences, $(\mathrm{h})$ volunteerism and service, (i) religious rituals, ceremonies, and traditions, (j) mental illness, (k) mindfulness and meditation, (l) temperament and personality, (m) agency and personal choices, (n) sexual orientation and experiences, and (o) generative devotion.
\end{abstract}

Keywords: youth religious/spiritual development; positive religious/spiritual development; family relationships; adolescent religious exploration; American Families of Faith project

Religious and spiritual development in youth is a growing area of scholarship (Benson et al. 2003; King and Boyatzis 2004; Roehlkepartain et al. 2006). Calls have been made to study youth religiosity and spirituality in the context of family relationships (Boyatzis et al. 2006). In this article, we highlight the contributions of the findings from a part of the American Families of Faith ${ }^{1}$ national research project (Dollahite and Marks 2019; Marks and Dollahite 2017), highlighting findings from one part of that project-studies focused on youth and their parents from diverse faith communities ${ }^{2}$ (within Christianity, Judaism, and Islam). Specifically, we discuss what our findings suggest for positive religious and spiritual development, particularly in family contexts.

What is religious and spiritual development and why does it matter? Benson et al. (2003) have defined spiritual development as "the process of growing the intrinsic human capacity for self-transcendence, in which the self is embedded in something greater than the self, including the sacred" (p. 207). On a related note, King and Boyatzis (2004) summarized why studying spiritual development in youth is potentially so valuable:

\footnotetext{
For information on the American Families of Faith project, please see http://AmericanFamiliesofFaith.byu.edu.

2 This review article overlaps with other articles we have already published because this article is a review of some of our previous work-with a focus on our research that has explored and examined different aspects of positive religious/spiritual development. A central feature of in-depth qualitative work like ours is that the core findings are illustrated by nearly 100 direct quotes related to religious/spiritual development from the parents of youth and from youth themselves. We are pleased to present here a composite of several of the most important findings that our small body of related empirical studies on youth have yielded.
} 
In adolescence, many youths turn toward religion and greater civic involvement, and yet many others who turn away from religion join either gangs or hate groups or become anti-social in other ways. Thus, adolescents' spiritualty and religiosity can be articulated and engaged, stifled and thwarted, or misdirected. This is an age period of intense ideological hunger, a striving for meaning and purpose, and desire for relationships and connectedness (p. 2).

Religiosity, spirituality, and positive youth development. There is evidence that religiousness and spirituality in youth is associated with positive religious/spiritual development (Boyatzis et al. 2006; Dowling et al. 2010; James and Fine 2015; James et al. 2012; James and Ward 2019; King and Boyatzis 2004; Hardy et al. 2019; Smith and Denton 2005) and a large number of positive outcomes including moral development (Hardy et al. 2018; Volling et al. 2009), parent-adolescent relationship quality (Bengtson et al. 2013; Kim-Spoon et al. 2012), psychological wellbeing (Petts 2014), identity formation (Armet 2009), less violence (Salas-Wright et al. 2014), reconciliation in families (Dollahite et al. 2019a) and a variety of other positive outcomes (Smith and Denton 2005). This has been explained, in part, by the ability of a faith community to provide youth with increased social capital (Ebstyne King and Furrow 2008; Smith 2003).

Note on terms. We use the phrase "positive religious/spiritual development" throughout the article. By "positive", we mean religious and spiritual development that contributes to the personal wellbeing of the youth and those around her/him. By using the term "religious/spiritual", we include more institutionally-oriented religiosity such as involvement with a faith community, religiously-inspired service projects or mission trips, and involvement in religious youth groups as well as more personally-oriented spirituality such as a relationship with the Divine, personal prayer, engaging with sacred texts, meditation and mindfulness, and so forth. By "development", we mean personal growth and maturation in religious and spiritual matters.

Generative devotion. In this article, we will draw our ideas on positive religious/spiritual development from our theory of Generative Devotion (Dollahite et al. 2019b), a theory that we developed based on nearly two decades of scholarship with the American Families of Faith project that has resulted in more than 70 scholarly articles and chapters and two books (Dollahite and Marks 2019; Marks and Dollahite 2017) addressing the nexus of religion and family relationships. Our American Families of Faith project is consistent with a positive psychology and positive youth development (PYD) approach in that we have interviewed a sample of religiously exemplary youth and parents (referred to us by their respective clergy). In those interviews, we focused on and explored personal and relational strengths associated with religious beliefs, practices, and communities.

For us, positive religious/spiritual development involves growth toward what we call Generative Devotion, defined as a way of approaching religious and spiritual beliefs, practices, and communities that attends to the long-term wellbeing of family members, is essentially other-oriented, responds to abiding needs of persons, respects the agency of others, and is consciously relational in nature. Generative Devotion is a process of continually becoming a better family member, one who approaches one's religious beliefs, spiritual practices, and faith community in ways that establish and nurture enduring, devoted family relationships across generations.

Grounded in the idea of Generative Devotion, we propose that positive religious/spiritual development involves growing in ways that are more likely to result in tending to the long-term wellbeing of others, becoming respectful of other persons' agency, being responsive to others' needs, and to being committed, loyal, and faithful to God, to family relationships, and to other human beings across time and generations. One core process of Generative Devotion is generative family conversations about how best to engage in healthy (i.e., generative) personal and relational processes grounded in respectful, responsive, and engaged relationships. For detailed explanations and illustrations of the theory of Generative Devotion, see (Dollahite et al. 2019b). This concept also harmonizes with Bengtson et al. (2013) finding in their longitudinal work that warm, close parent-child relations tend to yield significantly higher levels of religious transmission-a finding that held across parent and child gender. 


\section{Sampling and Participants}

Interviews used in the published studies summarized in this article were conducted as part of the American Families of Faith project (see http://AmericanFamiliesofFaith.byu.edu). The project is an ongoing effort to explore the nexus of religion and family relationships. A strengths-focused approach was employed with exemplar families (Damon and Colby 2013). Religious families were intentionally sampled in a two-stage selection process. First, religious leaders were asked to recommend families in their congregations they considered "strong in their faith" and "successful in their family relationships" to be interviewed. Secondly, recommended families were contacted to assess their willingness to participate. More than $90 \%$ of the referred families consented to be interviewed. In addition to the aforementioned process, snowball or participant referral sampling was sometimes employed among more difficult-to-access faiths (e.g., Islam, Orthodox Judaism). Overall, as of 2018, these procedures resulted in a total of 198 families ( $N=476$ individuals) being interviewed.

Samples for youth-focused studies. For this article, of the six studies we summarize below, the first four were focused on youth and the latter two were focused on parents. The samples in the first four studies included 49-55 families with 80-84 youth (depending on the selection criteria for each of the four studies). To recruit the participant families that included youth, we contacted religious leaders of different faith communities in New England and northern California and asked them to recommend families in their faith community with at least one adolescent child and whom they felt well represented their faith community in terms of religious activity level, devotion, and practices of the faith tradition. These families were contacted and asked to participate in the study.

The families were from three major branches of the Abrahamic faiths: (1) Christian (Baptist, Catholic, Christian and Missionary Alliance, Christian Science, Congregationalist, Episcopalian, Greek Orthodox, Jehovah's Witness, Latter-day Saint, Lutheran, Methodist, Pentecostal, Presbyterian, and Seventh-day Adventist); (2) Jewish (Conservative, Modern Orthodox, Reform, and Hasidic) (3) Muslim (Shiite and Sunni). The adolescents were interviewed in a family group setting including the parents and any adolescents in the family who were available and consented to be interviewed. In any given family the number of interviewed adolescents ranged from 1-5, with the mean number of siblings per family group being 1.6. The samples for the four studies that focused on youth included 80-84 adolescents (41 female, 39 male; age range 10-21 years; $M$ age $=15.1$ ).

In an effort to gather the richest data possible about the adolescents' lives, the adolescents and their parents were interviewed in their homes. This setting allowed the interviewer to "triangulate or obtain various types of data on the same problem, such as combining interview with observation" 3 (Corbin and Strauss 2008, p. 27). The adolescents and the parents were given the opportunity to respond to the questions, providing multi-respondent perspectives.

The interview guide for the adolescent interviews consisted of 26 open-ended questions that were used to guide the conversation. Often follow-up questions were used to clarify the adolescents' and their parents' responses to the original questions. The interviews were recorded and transcribed verbatim. This project was completed with IRB approval.

\section{Summary Findings from Six Studies}

In this section, we briefly present major findings from each of six published articles and illustrate the findings with some quotes from youth and their parents that were present in the original articles. ${ }^{4}$ We use the original article titles as the headers for the subsequent six sections.

3 Each of the original six articles utilized qualitative approaches to data analysis that included modified grounded theory, content analyses, and theory-based analyses. For details please see the methods sections of the articles.

4 We encourage readers who would like "the rest of the story" to read the six articles from which we draw this summary essay. In presenting summaries of major findings, we have left out most explanatory and transitional statements present in the original articles. Additionally, to illustrate each theme in the findings, we only include one or two quotes from youth and parents while in the original article, typically, there were several for each reported theme or finding. We discuss the articles 


\subsection{Study 1. Talking about Religion: How Religious Youth and Parents Discuss Their Faith}

In this study (Dollahite and Thatcher 2008), we analyzed "religious conversations" (meaning conversations about or influenced by religion) using grounded theory methodology. We were guided by the following research questions: (a) What is the context of parent-adolescent conversations on religious issues? (b) What are the processes involved in parent-adolescent conversations involving religion? (c) What qualities of conversational processes are most beneficial for the religious exploration and development of youth? ${ }^{5}$

Findings included responses from parents and youth, including when they spoke of one another. Parents and youth reported both positive and negative elements of their religious conversations. Parents and youth were frank about both their frustrations and satisfactions with such discussions. Two main conversational processes were identified: parent-centered and youth-centered. In this summary, we focus on youth-centered conversations.

Many parents expressed understanding of the needs of their children during religious conversations and tailored the conversations to try to meet those needs. These more transactional approaches encouraged the adolescents to be more active in the conversations.

Youth-centered conversations had the following elements: (a) youth talks more and parents listen, (b) youth seeks and receives understanding from parents, (c) religion is related to the youth's life, (d) conversation is open, and (e) parent-youth relationship is nurtured.

Youth talks more and parents listen. Rachel ${ }^{6}$, a Hasidic Jewish mother, said, "We find the older kids get, they have so much to say, and ... after a whole day of school, they come home and they don't want to hear us talk, they want to talk." Kira, a Lutheran mother, explained that, "I've learned that less words are better."

Youth seeks and receives understanding from parents. Mandy, a 15-year-old Christian daughter, said, "They're always willing to talk to me about any questions I ha[ve]. [T] hey explained what they believed to me." Sophie, a Presbyterian mother, said, "Sometimes I have an answer for him [adolescent child] and sometimes I go, 'You know, you've got a point.'" Kelsey, a 13-year-old Orthodox Christian son, commented, "Sometimes my parents don't know the answer so then it's ... a discussion because they don't have the answer to give me." Yuusif, an East Indian Muslim father, said that one way he approaches religious conversations with his children is, "explaining to them in a way they can understand ... and reason[ing] with them."

Religion is related to youth's life. Scott, a 14-year-old Catholic son, said about his parents: "I just feel like they always try to bring religion into our lives and to make us better." Paul, a 46-year-old Christian Scientist father of two said, "I think the time where it comes most to its surface is applying what we know and believe at times of conflict." One Muslim father said, "[W]hen something happens by way of a trial, [we show them] how to be patient and also to be assured that there's going to be good in that too, because it has come from God." Shawn, a Baptist father, speaking of family devotions, said: "There's always the challenge of ... helping them see the usefulness [of faith]."

Conversation is open. Alecia, a 20-year-old Latter-day Saint daughter, spoke from the perspective of a youth by saying, I enjoy talking [with my Mom] about religion.... [W] hen we're just talking as friends ... on a casual basis, it's usually pretty cool.... I'll say something to [my mom] about religion and she'll be like, "Yeah, that's awesome. I have a story that goes with [that point] you were talking about."

in order from earliest published to most recently published. We emphasize quotes from youth but also have included quotes from parents.

5 More specifically, we asked 26 questions of parents and youth covering various topics on how religion influenced parent-child relationships. The following questions were most relevant to those research questions: How do your parents share their faith with you? When you talk together as parents and children about religion, how does the conversation go? How have your parent-child conversations about religion influenced parents and children? What do you consider to be the most important things for you to be or do as a mother or father of faith? As parents, how do you share your faith with your children?

6 All participant names in all six studies are pseudonyms. 
Aisha, a 46-year-old African-American Muslim mother of 11, said:

We talk a lot. We have very in-depth conver sations because ... they're very verbal. They have their opinions.... [T]hey're allowed to express themselves, even if they disagree with us.

Arella, a 42-year-old Conservative Jewish mother of two, said, "Jews are very open.... They're out there. No one holds back." Esther, a 12-year-old Conservative Jewish daughter explained, "Well, it's kind of a stereotypical thing that we [Jewish families] argue a lot, but it's true."

Parent-child relationship is nurtured. Dawuud, a Muslim father, reported his desire to be "constantly alert with them and close to them in understanding what they're going through." Amy, a 45-year-old Baptist mother of two, said she tries to compliment her kids and be a friend:

I [am] trying to encourage them and to just and let them know how much I respect and admire them and appreciate them as people. ... I still play with my kids; and I'm very affectionate and I hug them. And even though I'm their mother, I'm also their friend.

Jack, an 18-year-old Baptist son, said that the parents of some of his friends neglected the parent-youth relationship in their efforts to share their faith:

I've seen some of my friends ... where parents are slamming Bible verses in their face, and really not loving them, not helping them grow. It's more like a forceful thing, at unnecessary times, when it really would have been helpful just for them to sit down and talk with their kid.

Study 1's implications for positive religious/spiritual development. The core concept Study 1 yielded was: when parent-youth religious conversations are youth-centered, the emotional experience is more positive for parents and youth than when they are parent-centered. This concept is consistent with previous theory and findings about the fact that the quality of parent-child interactions matters more than the content of conversations in facilitating positive religious/spiritual development in youth. The findings of Study 1 supported a core process of Generative Devotion: generative family conversations. In order for most youth to experience positive religious/spiritual development, they need to be involved in meaningful religious conversations with their parents and other family members. To the extent that those conversations are generally consistent with the features of youth-centered conversations, youth are more likely to report feelings positive about their faith, their parents, and the religious conversations they engage in with their parents. Growth toward Generative Devotion is more likely when adults engage youth in conversations about religious/spiritual development in ways that honor the agency of youth, respect the opinions and emotions of the youth, are oriented toward building and strengthening relationships with God, with family members, and with others in and out of the faith community. In a phrase, Study 1 indicates that to foster positive religious/spiritual development, parents need to listen more and preach less-including when conversations involve religion.

\subsection{Study 2. Giving up Something Good for Something Better: Sacred Sacrifices Made by Religious Youth}

One nearly universal aspect of religion is that it tends to ask something of adherents that takes them outside or beyond themselves. Parents are expected to make sacrifices for their children, but in contemporary Western culture parents are rarely encouraged to ask their children to make meaningful sacrifices. Study 2 (Dollahite et al. 2009) explored the questions: (a) What sacrifices are highly-religious youth making for their faith? and (b) Why are they willing to make sacrifices for their faith? Analyses indicated that adolescents reported sacrifices in five areas, briefly outlined next.

Societal expectations. A 17-year-old Hasidic Jewish daughter said, "In this day and age for someone to [say], 'I want to be a mom,' ... everyone kind of looks at me funny. [L]ast year ... my English teacher ... said, 'How many of you daughters want to have a career as opposed to be a mother?' and I didn't raise my hand. And she was sort of taken aback."

Popular culture. A 16-year-old Presbyterian son said, "I think the biggest thing that I've had to give up is the temptation of when you're my age, of just going out and ... doing what your impulses tell you to do." 
Comforts and pleasures. A 14-year-old Catholic daughter said, "[M]y friends ... ask if I want to spend the night [and] ... I'll just have to say, 'No, because I have to go to church in the morning,' and they'll just be like, 'Can't you just miss one week?' ... And, nope."

Time and activities. A 13-year-old Latter-day Saint son said, "I'm on a basketball team right now, and they have tournaments almost every weekend on Saturday and Sunday and so I go to the games on Saturday, [but] on Sunday, I don't go to them because I'm trying to keep the Sabbath day holy. I go to church with my family."

Peer relations. An 18-year-old Baptist daughter said, "I've ... not had a very active social life because almost everything that most of my friends at school are doing is something that I don't feel would be glorifying God."

The second research question addressed in this study was "Why are youth sacrificing for their faith? Responses were coded into five categories, as reported next.

Connecting to a higher meaning or purpose in life. A 20-year-old Lutheran daughter reported, "I'm often finding myself giving up the bad or even the good for the best ... [including] not going out with any guys ... [who] are spending their entire summer right now drinking and partying every night. ... I [am] giving up what the world thinks is good to get the best."

Connecting to God. An 18-year-old Muslim daughter explained, "I don't think that it's a matter of sacrifice because like we said, life is [the chance] for [us] to get to paradise. And any smart person would want the best ... anything in this earth can go away. ... but ... [the] afterlife ... it's not something that can be taken away."

Connecting to the faith tradition or community. A 12-year-old Jewish daughter reflected, "Well, [the sacrifice is] worth it because being Jewish is very special and we're different, and I kind of like that a little bit. And I'm willing to make sacrifices [to] be Jewish."

Fulfilling expectations. A 14-year-old Catholic son explained, "I've been the one on my soccer teams that's missed a lot of games. I lost lots of games over church or CCD [religious education]. And like right then, I really hate it. ... But ... [some] people I've talked to, they actually say, 'It's going to be good for you.' And I guess I kind of trust that."

Feeling affective benefits. When asked why he was willing to sacrifice for his faith, a 16-year-old Presbyterian male answered, "I think that it's because when all is said and done and when the parties are over and the day after, it feels so right and I feel so thankful for my decisions [not to party]. And I judge a lot of my decisions in the past by how I felt the day after I made the decision."

Study 2's implications for positive religious/spiritual development. Study 2's findings indicate that making religious sacrifices, including financial ones (Marks et al. 2009) remains influential in the lives of many religious adolescents. Furthermore, we see that some adolescents are making these sacrifices for their faith in visible, public ways-including avoiding partying and activities not consistent with their faith, as well as sacrificing to honor their faith's holy days (e.g., Sabbath). Additional data not reported in the present article indicate that youth are also making these kinds of faith-related sacrifices in private ways-such as engaging in personal prayer or scripture study instead of watching TV or playing video games. The findings of Study 2 should be encouraging for religious parents and leaders since they indicate that many religious youths take their spiritual and religious identities seriously enough to make significant sacrifices for God and for their faith, both publicly and privately. The findings suggest that religious parents and leaders should help youth to identify and consider the reasons why they are more or less willing to make sacrifices for religious reasons and how those sacrifices may influence their religious/spiritual development. Adults who can help youth to both reflect upon and strengthen their religious commitments may be better at supporting youth as they live their faith. Growth toward Generative Devotion is more likely when youth are non-coercively willing to enact their inner spiritual values, identities, and commitments by making meaningful sacrifices for God, for others, and for future generations. 


\subsection{Study 3. Anchors of Religious Commitment in Adolescents}

Our third study (Layton et al. 2011) explored adolescent religious commitment. Based on interviews with youth and their parents, we proposed a new construct, anchors of religious commitment, to describe what youth committed to as a part of their religious identity or, in other words, where they focused their commitments. Commitments connected the youth to someone or something else. Study 3 identified the following seven categories of anchors of religious commitment. Next, we briefly report on the major findings for each anchor of religious commitment, including some explorations of variations of each anchor.

Commitment to religious traditions, rituals, and laws. The most frequently mentioned anchor of youth religious commitment was commitment to religious traditions, rituals, and laws. One 10-year-old Jewish daughter articulated various celebrations that were meaningful to her:

I like Hanukkah. ... [I]t's just, it's fun to be able to light your own menorah, and to invite friends over to come do it with you ... and Purim is fun because you get to dress up, and Pesach [Passover] is fun because the whole family's there and all that sort of stuff.

A Catholic mother of a 15-year-old son and a 13-year-old daughter said that religious rituals were "the little things that we do that have that spiritual meaning to us." A 15-year-old Catholic son said that religious rituals were important to his personal religious identity,

Compared to other kids my age, I think I'm pretty religious, 'cause I go to church every Sunday. I pray every day. I altar serve. I go to CCD [religious instruction]. And religion is a big part of my life.

An 18-year-old Muslim daughter asked about her commitment to cover herself with the hijab said, "I look at it basically as just obeying the laws of my faith."

Commitment to God. Some youth said they were committed to God as a source of authority, as did a 19-year-old Jehovah's Witness daughter: "We appreciate the fact that He's our Creator-and who better to give us guidelines for how to live our lives?" A 15-year-old Catholic son said, "Being religious is kind of like you have another friend. It's God and Jesus; you just feel like you're able to lean back on someone, if the going's tough." Speaking of his commitment to marry a Christian woman, a 21-year-old Baptist son said, "Well, I think, again for reasons of trust. First of all, I think it would be the most pleasing to God. It's what He would want." A 15-year-old Christian daughter said, "Well, now that I'm thinking about getting a career and everything, He's my counselor, and so I would like to do something that would be in His will."

Commitment to faith tradition or denomination. Commitment to their particular faith tradition as an anchor of commitment, was expressed by some youth such as a 15-year-old Muslim son, who said, Islam is not just something you're doing at certain times of the week ... It's real, like you do it all day ... it's part of what you do. Part of the way you eat, the way you treat other people.

A 20-year-old Jewish son described himself as "taking on an ethical and moral framework provided by Judaism." A father of a 15-year-old Lutheran daughter said,

The values that we like are in the church system. We're not really happy with the values that we see in American culture, a lot of consumerism [and] ... greed.... [S] o we bring them to church, to get this whole other value system.

A 20-year-old Orthodox Jewish son spoke of his father's commitment to Judaism and how this had influenced him:

$[\mathrm{H}] \mathrm{e}$ 's someone who feels very much sensitive to the Holocaust and having lived ... just after it that he felt ... the weight of all of the sacrifice that had been made for three thousand years so that a father could pass to their son ... the knowledge that we're Jewish and this is what it means. 
Commitment to faith community members. Speaking of how her decision of where to attend college was influenced by the members of her faith community, a 17-year-old Orthodox Jewish daughter said,

I visited the Chabad [Jewish Student Center] on campus, ... I met the rabbi, I really liked the family and that has really dictated why I'm going there ... [I loved] the religious community.

A 20-year-old Lutheran daughter said, "There's a lot of strength that I draw from being able to share communion with other believers and the reminder and the forgiveness that comes through that is definitely ... strengthening." A 15-year-old Episcopalian son said,

When I talk to my friends, if I say I have to go to church or something, they immediately think it's a bunch of old people and they think I'm just being dragged along. But there's a lot of people [there]; and it's a fun place.... I look forward to going to church to see those people.

When asked about her choosing to be an altar server, a 14-year-old Catholic daughter said, "I just like serving the church. It makes me feel good that I'm serving the community." A 14-year-old Jewish son discussed why he experienced a renewed commitment to his faith:

The first time when my parents took me to [synagogue], my mom came downstairs and was dancing around the bimah [Torah podium].... I was having a fun time. And so after kiddushin [prayer of sanctification] and everything else, after dinner I said to my mom, 'Can we come back here again?' And so that's when I started getting more and more religious.

Commitment to parents. Another common anchor of commitment for the youth was their parents. A 20-year-old Lutheran daughter said, "Dad's the spiritual head of the family." A 15-year-old Episcopalian son said,

My mom wants me to go to church, and my dad.... [S]ometimes I'll want to hang out with a friend on Saturday night, but I have to go to church the next morning. And that's not an issue, I'm going to church the next morning.

A 14-year-old Latter-day Saint son mentioned his parents when asked why he doesn't drink religiously proscribed beverages when he was with friends, "They've taught me not to do that and I respect them." A 17-year-old Muslim daughter mentioned her respect for her parents and Islam, "I want to be able to fulfill my duty in Islam upon my parents ... and I wouldn't want them to be questioned about why wasn't I obeying the rules of God."

Commitment to scripture or sacred texts. Another common anchor of religious commitment was sacred texts, an 18-year-old Baptist daughter spoke of how her sacred texts gave her answers to important questions:

I just remember sitting in English class last year and we were discussing a lot of things and I just remember sitting there thinking how confused I'd be on this earth if I didn't have the Bible and God's standard and morality to live by.

Commitment to religious leaders. The last anchor of religious commitment evident in Study 3 was commitment to religious leaders. The two main forms of this commitment were to leaders as a source of authority and as a relational support. Referring to the authority of a religious leader, a 13-year-old Latter-day Saint son said, “The prophet, he's the guy who's in charge of our whole church for the whole world, [has] asked us not to [drink alcohol] and so that kind of guides our life." A 14-year-old Orthodox Christian daughter discussed how when she is an adult she wants to have a meaningful relationship with a religious leader, "I [will] ... consult with a spiritual father [my church leader].... [I want to] have that base and [those] connections with the church."

Study 3's implications for positive religious/spiritual development. The findings of Study 3 indicated that there are many "anchors" that enhance, facilitate, and empower the religious and 
spiritual commitments of youth. This should be encouraging for religious parents and leaders since it implies that there are many ways that youth might feel connected to their faith. Adults who understand this might consider how the youths they know and love are anchored to their faith and if there may be ways to build on those connections and commitments as the youth develops. Growth toward Generative Devotion is more likely to occur if youth have more (and deeper) anchors of religious commitment. Generative adults can inquire of youth what they consider to be the most meaningful anchors to their spiritual and religious commitments and support them in their efforts to deepen, strengthen, and find meaning in those connections.

\subsection{Study 4. Religious Exploration among Highly Religious American Adolescents}

In some ways, of the six studies summarized in the present article, Study 4 (Layton et al. 2012) is the most relevant to issues of religious/spiritual development in youth because it provides information on how youth engage in spiritual and religious exploration as they develop. Issues surrounding religious commitment and exploration are important to adolescents, parents, religious leaders, and the researchers who study them. This study broadened our understanding of religious exploration to include catalysts of exploration and strategies for exploration that involved using established commitments as resources in the exploration process. The insights gained from interviewing Jewish, Christian, and Muslim adolescents suggested the importance of moving beyond conceptualizing religious exploration as merely a matter of whether or not adolescents have significant religious doubts. While doubt matters in some cases, it does not fully explain the processes in active exploration or the processes through which doubts arise and are addressed in religious youth.

The relationships in the lives of youth reportedly provided living models and exposure to different beliefs and manifestations of religious teachings. Youth explored the religious beliefs and practices they have grown up with and tended to compare that with who they were and who they were becoming. These explorations may or may not be considered doubts by the youth, but were an important part of their religious identity formation.

\subsubsection{Study 4's Catalysts of Religious Exploration}

Study 4's analyses identified six catalysts that led adolescents to think about, question, doubt, and/or experiment with their faith in greater depth, as outlined next.

Examples of different ways. A 16-year-old Presbyterian son stated, "Recently a good friend of mine ... converted to Buddhism ... He decided to do this simply because of research and trying to figure [things] out. To him, the Bible didn't quite make sense and the teachings of the Buddha made much more sense to him.... [That has got me] thinking about what I want to get out of my religion."

Learning new things. A 12-year-old Jewish daughter spoke of the things she had learned in her Torah class about the story of Noah and the ark which stretched her to ask questions about things she had never considered before.

Normal development. An 18-year-old Baptist son discussed his religious/spiritual development by saying, "I'm still a work in progress.... I'm convinced more and more it's just a continuing process."

Times of stress or crisis. A 15-year-old Lutheran daughter spoke of prayer during hard times, "I mean anytime we have a problem ... we come home and we [are] like, 'I can't take it anymore. This is too hard' and we always end up with, 'Well, what does the Bible say about it?' Then it goes to prayer."

Leaving home. An 18-year-old Baptist son described the impact leaving for college had on him: “This year in fact especially, like entering the University ... and applying to be a philosophy major, lots of questions come up. I keep having to ask myself, 'What do I really believe? What do I believe about this?'”

\subsubsection{Study 4's Strategies for Religious Exploration}

In this study, we also learned about five diverse strategies of religious exploration that youth reportedly employed, as addressed next. 
Asking questions and having conversations. Youth spoke of the amount of freedom of individual thought that their parents encouraged. A 17-year-old Baptist son said, "First, one of the key things that my parents did, which I am very grateful for, is they ... give us a good amount of freedom to think, to process."

Pondering and self-reflection. One 18-year-old Baptist son discussed his use of the process of self-reflection in his religious exploration by explaining, "I think a lot of my friends and people that I work with are sort of operating, thinking short term, not thinking about consequences. But I think one thing that I've been really challenged to think about [is] ... what are the consequences of these actions?"

Having personal experiences. Some youth mentioned personal experiences with their faith development including a 20-year-old Muslim daughter who said, "I know that if I get lazy and if I don't want to pray for a week or [do] not open up the Qur'an ... I literally feel ... [a] restless sensation, like something's missing in my life."

Learning from experiences of others. A 17-year-old Baptist son mentioned that he learned from watching how his mother worked through the death of her brother. He reported, "Seeing my mom going through these stages in life with her brother dying, it really teaches you how important ... your [faith] community, your immediate family is."

Appealing to authority. A 16-year-old Presbyterian son said of his parents, "I go to my parents and they seem to be the wisdom that is passed down to me so that the contradiction can be resolved." A 16-year-old Latter-day Saint son also described how the experience of his parents raising his older siblings helped them guide him better, "My parents have had a lot of experience. They can offer advice that really helps in certain situations.... I'm lucky. 'Cause I'm the last one, I think the other three kids helped them to be able to guide me better."

The five preceding strategies of religious exploration among youth are of value when considering the important issues of whether youth choose to remain or leave their familial faith.

Study 4's implications for positive religious/spiritual development. One of Study 4's most important findings was that commitments (or "anchors" as discussed in Study 3) seem to be valuable resources that adolescents use as part of the ongoing process of religious exploration. We also learned that religious exploration is not typically a single event where all parts of religious belief and identity are put on the table at once. Instead, typically it is a process where youth tend to explore certain parts of their religious identity while holding others constant as commitments. This approach to understanding adolescent religious identity and exploration is novel. These findings also suggest that parents and youth leaders can expect and should support an active process of religious and spiritual exploration among their youth in their families and congregations. Adults who understand that it is normal and healthy for such exploration to occur are more likely to provide youth the space they need and want, while being there as a stable, supporting, and faithful resource for them. Growth toward Generative Devotion is more likely when adults (a) assist youth to learn how to hold to core religious commitments while seeking answers to religious questions, (b) encourage youth to stay connected with religious leaders while searching for resolutions to their religious doubts, and, especially (c) encourage them to remain in positive relationships with family members while exploring their religious identity.

\subsection{Study 5. Beyond the Bucket List: Identity-Centered Religious Calling, Being, and Action among Parents}

Study 5 (Dollahite et al. 2018b) explored the answers given by practicing Christian, Jewish, and Muslim parents of adolescents to the question, "What do you consider to be the most important things for you to be or do as a mother/father of faith?" Through this question, we explored various dimensions of identity-centered religious calling, being, and action among religious parents regarding their parenting.

In Study 5, there were three primary findings. Parents' responses focused on (a) being an example, being authentic, and being consistent; (b) providing support, love, and help, and (c) teaching values, tradition, and identity. Each category and selected subcategories will be discussed below, with illustrative quotes from the religious parents we interviewed. 


\subsubsection{What Religious Parents Felt Called to Be}

Parents described what they believed they needed to be in three respects: be an example, be authentic, and be consistent.

Be an example. A Latino Catholic father spoke of his own father's example and how he wanted to also be "a good example" for his kids: "I had a fantastic example in my father. My father was, and he is still, an incredible example for me. And I think that if I can pass some of that to my children through my own example, through talking or teachings or verbal example [that would be great]."

Be authentic. A Conservative Orthodox Jewish mother spoke of authenticity: "I presented to [our children] an ever-expanding view of Judaism and that I was always honest about my anger with the religion, anger with the Rabbis, my own distress about the religion. [I wanted them to know] that whatever I chose to give them from the more Orthodox approach was something that I really believed in."

Be consistent. A Methodist father shared, "[I want] to be consistent, even if it's a consistent pain in the neck." A Lutheran father similarly said, "[I want to] set an example ... in my daily life. Just to be somebody who's got ... a soul ... who's not interested just in the short-term things.... That and family, and all these things are important.... That's important to me."

In addition to being certain things for their children, many parents also discussed domains where they felt an obligation — even a sacred duty—to provide, as discussed next.

\subsubsection{What Religious Parents Felt Called to Provide}

Mothers and fathers described what they felt they were called to provide in three areas of life: support, love, and help.

Provide support. A United Church of Christ father spoke about being present in his children's lives: "I think a lot of it is just being there and spending time with my children, and listening to them and playing with them. Challenging them to do better." A Catholic father, in discussing being supportive, added, "Certainly you've got to be the motivating force that takes them through a lot of those things they don't want to do."

Provide love. A Latter-day Saint father spoke of loving his children, "I want my kids to know ... even though I ... have frailties of losing my temper, raising my voice inappropriately, that I love them ... I love them .... and care about them."

Provide help. An East Indian Muslim father said that part of his job is "to always look for [my children's] welfare and be available to them, to help them through the various situations they face." A Conservative Jewish father said, "The most important thing is to make sure the kids are safe.... It's a dangerous world and you want to protect your kids."

\subsubsection{What Religious Parents Felt Called to Teach}

Religious parents felt called to teach their children in three domains: religious values, the faith tradition, and religious identity.

Teach religious values. A Baptist mother said, "I've tried to be honest about teaching them right from wrong from a Biblical perspective." A Catholic mother, explained her desire as a mother: "Teach them values I'd want them to have forever and ever." A Pentecostal father said,

"[I] keep instructing my children to always be confident in the Lord ... regardless of what the situation is ... I try to instill good Christian values into my children."

Teach the faith tradition. Parents described ways they tried to share their faith with their children. A Jewish mother said,

[I] try to pass on the traditions that are special and that are important.... [I]n the house what I teach them is: This is how you set a Shabbas table, and these are the foods that you prepare for a traditional Sabbath meal, these are the foods that you prepare for a traditional Rosh Hashanah, which 
is [the] New Year's [celebration].... I think teaching them how to make a Jewish home [is important], so that when they have a Jewish home, [they won't have] to look in a book.

Teach religious identity. A Muslim father discussed how his children have learned to stand up for their Islamic identity:

If they have struggled, the biggest struggle ... has been because they look different, they do different things, they dress differently. And they have considerable peer pressure. For example, they don't date, they don't drink, they don't dress in certain ways, so there are some restrictions that they feel. And we have tried to provide them some alternatives for entertainment and things, and also to explain to them that: 'Yes, you are different than everybody else, and you should be proud of the difference ... Hopefully we give them enough support that they can be themselves.

Study 5's implications for positive religious/spiritual development. In Study 5, we explored what exemplary mothers and fathers of various faiths considered most important for them to be (being) and to do (action). Mothers and fathers not only wanted to teach their children about their religious beliefs, they also reportedly strove to become models of what they were teaching their children. Many reportedly drew on a commitment to God and their religious faith as a guide for what and how they should be as parents. The findings of this study suggest that many parents are deeply devoted to their adolescent children's religious/spiritual development (as well as their overall development). Indeed, in many cases, the identities as "mothers and father of faith" were centered on being what they believe God desires them to be in order to help their children know and love God (and/or their respective religious tradition). Being the kind of parent that lovingly and authentically helps their children experience positive religious/spiritual development was, reportedly, the most important objective for many of these parents. We were inspired by parents' level of thoughtful commitment to God, by their commitment to their faith community and its members, and by their commitment to their children. Growth toward the kind of spiritual and religious life we call Generative Devotion was exhibited by many parents.

\subsection{Study 6. Beyond Religious Rigidities: Religious Firmness and Religious Flexibility as Complementary Loyalties in Faith Transmission}

The sixth and final study (Dollahite et al. 2019c) we will discuss explored how religious parents strove to balance firmness and flexibility in their efforts to transmit or pass on their faith to their children. Pew Research Center (2009) found that $44 \%$ of Americans reported that they had left the religious affiliation of their childhood. Additionally, more recent national data indicate that $78 \%$ of the expanding group of those who identify as religiously unaffiliated ("Nones") reported that they were raised in "highly religious families" (Pew Research Center 2016). We suggested that this may be, in part, associated with religious parents exercising excessive firmness with inadequate flexibility i.e., rigidity. We found examples of (a) religious firmness, (b) religious flexibility, and (c) efforts to balance and combine firmness and flexibility. Examples of firmness and flexibility included those related to (a) religious practices and (b) religious beliefs, as outlined next.

Firmness in family religious practices. A Lutheran mother said; "I can't imagine not going to church on Sundays. And as ritual as that is, I just can't imagine not [going]." An African American Baptist father said, "There are Sundays when [the kids] don't want to go, [but still] I said, 'We have to, you have to go to church.' I mean, that's just a practice of this family."

Flexibility in family religious practices. Martha, a Lutheran mother, said, "[T]here's probably a couple of times that we dragged [my son] to church and he wanted to do other things, or sports related things. But mostly we let him do his sports instead of church." Abigail, a Reform Jewish mother, shared, "[B]ecause we're tired on Friday night, we don't get to synagogue as much as we want to. And, because of other time commitments, there's just never enough time to do as much as maybe we should for the Jewish community." 
Integrated firmness and flexibility in religious practices. Banafsha, a Muslim mother, in connection with the religious practice of salat (Islamic prayer five times daily), shared an example that combined both firmness and flexibility: "We don't want to delay the prayer of anybody. If they are studying, they can pray in their room and keep studying [and] not wait for the other ones ... we didn't want to make it hard for anybody."

Many participants reportedly manifested both firmness and flexibility in connection with religious practices. We now move from practices to beliefs.

Firmness in religious beliefs. A Muslim father said, "If it is something that has already been prescribed religiously, then there is no discussion." A Chinese Christian mother shared her beliefs on marriage that stem from the Bible when she said, "This is the principle; we could not change the order."

Flexibility in religious beliefs. A Jewish mother spoke of her view regarding perspectives on gender in worship:

I have a problem with gender roles [in] religion in general, so I ignore them. I don't abide by them.... Like in Orthodox [Judaism], ... I don't agree with the idea of having women and men separated during ceremonies. Women are not allowed on the bimah [podium from which Torah is read] and you can't listen to a woman's solo voice and I just don't believe in that.

A Chinese Christian mother spoke of her view that tithing should be flexible:

We offer money at church. We all know how we should do, everyone should tithe. But this proportion should be flexible rather than fixed because the condition[s] of families are different. Those families which are in difficulties should adjust.

Integrated firmness and flexibility in beliefs. A Muslim father reflected a combination of firmness and flexibility in religion,

I do primarily look to the religion; however, I look into the secular things to the extent that if it's going to help me understand the situation we are up against [then I'll use it].... I look at [secular materials] to see how people think.

A Latter-day Saint mother, asked whether when confronting a problem she would personally turn to sacred or secular sources, reported, "I would read both. I would give more weight to what was said in the religious publication but I would read a lot everywhere, hoping to find [useful information]."

Implications for positive religious/spiritual development. In Study 6, we framed the processes of religious firmness and flexibility such that each process involves an important kind of loyalty. Thus, religious firmness is centered in loyalty to God and that which serves to directly uphold or represent God, e.g., sacred texts, faith tradition, faith community, and divine commandments. Religious firmness is often reflected in (a) religious beliefs that, due to perceived divine origin, are non-negotiable and not subject to personal abrogation, and is also evident in (b) religious practices that are held sacred and inviolable and thus take precedence over other nonreligious or personal activities. Such practices are often maintained even in the face of personal and familial inconvenience or preferences. Similarly, religious flexibility is centered in loyalty to family members (and other loved ones) by maintaining sensitivity to their needs, challenges, and circumstances. For faith communities and for families themselves, integration between these two complementary loyalties may be needed to optimize personal and family wellbeing in the context of acceptance of divine mandates and expectations. Our findings regarding religious firmness and flexibility suggest that parents who wish to best facilitate positive religious/spiritual development in their children would be wise to find ways to balance and integrate religious firmness and religious flexibility. Parents who desire the religious/spiritual development of their adolescent children to be positive and optimal would seek to engage with their youth in ways that respect their agency, their interests, their changing circumstances, and their daily schedules. 


\section{Summary and Suggestions for Future Scholarship}

In terms of understanding and promoting positive religious/spiritual development in youth, our work in the American Families of Faith project reflects our belief that it is important for scholars to explore (a) the ways that parents and youth talk with each other about religious and spiritual matters and how this dialogue influences positive religious/spiritual development, (b) the kinds of religious sacrifices that youth are asked to make and the reasons they are willing (or unwilling) to make such sacrifices and how these sacrifices influence positive religious/spiritual development, (c) the anchors of religious and spiritual commitment present in the lives of religious youth and how those anchors influence positive religious/spiritual development, (d) the catalysts of religious exploration in the lives of religious youth, the strategies they use in religious exploration, and how those relate to positive religious/spiritual development, (e) what religious parents believe are the most important things they can do to support and facilitate their adolescent children's positive religious/spiritual development, and (f) how religious parents can balance religious firmness with religious flexibility in ways that are more likely to promote positive religious/spiritual development in their adolescent children. The studies on youth, parents, and faith reviewed here suggest that positive religious/spiritual development involves a set of complex and dynamic processes that deserve careful study by scholars. Our own sustained study of religious youth and their parents has identified a number of related processes, as discussed next.

Importance of family context. Our work highlights the importance and benefits of studying youth religious/spiritual development in the context of their families-particularly with sensitivity to their parent-child relationships. We have found that interviewing youth and parents together allows for meaningful, candid, transactional, and insightful conversations about youth religious/spiritual development to occur. It is true that when adolescents are interviewed without their parent(s) present, the interviewee may feel freer to speak of difficult or sensitive issues. Solitary interviews would be more effective, for example, when exploring anti-social or high-risk behavior in youth. However, these have not been our aims in the American Families of Faith project. In the strengths-based approach we employ, we intentionally and purposively seek referrals to exemplar families and strive to uncover the secrets to the familial and religious success that clergy perceive in these families. With such an aim, the ideal approach and method are arguably different, and we posit that there are also informational benefits that can accrue when youth are interviewed with their parent(s) present. During interviews with parents and their adolescent children, we noticed that they reminded each other, challenged each other, filled in gaps, and otherwise complemented each other. Over the past two decades, we have found ourselves increasingly convinced of the utility and value-added contributions of employing what Handel (1996) has called whole family methodology. We believe that future scholarship on youth religious/spiritual development would continue to benefit from consideration of the ways that youth and parents (and ideally, siblings and grandparents) across many faiths influence youth religious/spiritual development.

Importance of diverse samples. Certainly, different research projects have varying aims, objectives, and widely ranging central research questions. Our work also has emphasized the importance and benefits of studying religious/spiritual development across diverse religious and ethnic communities using the same questions and methods of analyses. In terms of providing meaningful contexts for youth religious/spiritual development, our analyses of an array of eight religious-ethnic communities has demonstrated that there are both important similarities across diverse faiths and also important differences (Dollahite and Marks 2018, 2019; Marks and Dollahite 2018). Much work is left to accomplish. For example, in terms of diversity it is important to further explore how religious/spiritual development differs across various samples and contexts, e.g., religious, socio-economic, racial-ethnic, and national. We have begun some work in this area as manifest by a special issue (54:7) of Marriage 
and Family Review. ${ }^{7}$ The Marriage and Family Review special issue (and subsequent book, Dollahite and Marks 2019) is devoted to marriage and parenting across eight religious-ethnic communities (Asian American Christian families, Black Christian families, Catholic/Orthodox Christian families, Evangelical Christian families, Jewish families, Latter-day Saint families, Mainline Protestant families, and Muslim families). Multicultural and pluralistic efforts like this help to broaden and deepen the related empirical literature beyond the white, middle to upper-middle class, Christian samples that have dominated social science research on religion in the past (Jones 2016). The present special issue of Religions (edited by Professors Abo-Zena and Rana) is a richly diverse and textured example of what we envision for the future.

Contributions of qualitative data. In addition to calling for richer and more diverse samples and contexts, methodology is of vital concern in future work. We believe that it is important for scholars to bring a variety of methods to bear in the study of youth religious/spiritual development. Because we believe that it is important to carefully explore the in-depth perspectives of youth and parents, our work has emphasized qualitative methods (while in some cases combining these with basic and descriptive statistical analyses). By asking youth and parents to discuss their spiritual beliefs, religious practices, and faith communities in detail, scholars are able to learn first-hand about youth's ideas, experiences, values, concerns, opinions, and narratives regarding those things that most influence them.

We believe that an integrated mixed-method approach to measurement is most likely to yield in-depth, nuanced, and meaningful information about youth religious/spiritual development. Given the dynamic nature of religious and spiritual development, the varieties of lived experience, the existential wrestle of meaning making, and the complexities inherent at the nexus of faith and family processes, we have consistently advocated for gold-standard quantitative and qualitative research that is more fitting for the challenge than traditional, cross-sectional, correlational work (Marks and Dollahite 2011, 2017, 2018). We see a particular need for work that pushes past the "whats" to the "whys" (meanings) and "hows" (processes) involved at the nexus of faith and family life where youth development is impacted. To date, longitudinal (quantitative) and narrative (qualitative) approaches seem particularly promising (for examples of related longitudinal quantitative work, see (Bengtson et al. 2013; Smith and Snell 2009)). We are acutely aware that the approaches we are recommending are time intensive. If there is a short route to understanding the complexities at the nexus of faith, family, and youth development, we have been unsuccessful in discovering it.

It is possible to learn important things about youth religious/spiritual development using online surveys, particularly those that include open-ended questions (cf. Hardy et al. 2015; McMurdie et al. 2013). Textual response options allow youth and parents to write about their past and present spiritual experiences (or lack thereof) and important changes in their past to present religious/spiritual development (or lack thereof), allowing for process-oriented view to emerge, versus single, cross-sectional view (Marks and Dollahite 2011). We would make the analogy of comparing videos to snapshots. However, we believe that in-depth interviews can allow for even more fine-grained exploration of spiritual experiences and changes in religious/spiritual development. In sum, we believe that it is helpful to explore positive religious/spiritual development in various contexts: within the family, among diverse religious communities, among diverse ethnic communities, and using diverse methods (qualitative, quantitative, and mixed methods).

\section{What Are We Missing?}

In addition to the suggestions above, we also think it would be helpful to explore positive religious/spiritual development among youth in relation to the following: (a) social and political activism, (b) popular media and music, (c) participation in secular activities, e.g., sports, arts, gaming, (d) wrestling with BIG questions, i.e., questions involving Being, Intimacy, and God, (e) conversion 
and disaffiliation, (f) interfaith knowledge and experience, (g) impactful personal experiences, (h) volunteerism and service, (i) religious rituals, ceremonies, and traditions, (j) mental illness, $(\mathrm{k})$ mindfulness and meditation, (l) temperament and personality, (m) agency and personal choices, (n) sexual orientation and experiences, (o) the dark side of religion, and (p) generative devotion. While some of these have been explored in relation to child or adult spirituality, few have been investigated with youth. And while it might be difficult for any one study to address all these issues simultaneously, we think that looking at combinations of these issues would be of value. Because this section is not intended as a review of the literature, and because search engines make finding articles on various topics fairly straightforward, we will only cite a few studies on the topics mentioned.

Social and political activism. Emphasis on and excitement surrounding politics, social causes, activism, and other ways of trying to make a difference in society have surged since 2016. Exploring how such activism might flow from or influence a young person's religious belief and experience would be helpful. For example, youth could be asked if and how their religious/spiritual development intersects with social and political issues they care about, such as striving toward greater social justice, alleviation of poverty, fighting human trafficking, promoting gender equity, securing human rights, and fighting racism.

Popular media and music. Much of popular culture directed toward youth either ignores religion or portrays people who take their faith seriously in negative ways. Most popular music is quite secular and tends to promote values contrary to those espoused by most world religions. Mass media often portrays religious faith as irrelevant at best and an enemy at worst. It would be helpful to study how youth engagement with popular music and media are influenced by religious commitments and vice versa. For example, youth could be asked how they believe that their religious/spiritual development has intersected with religious and secular media and music.

Participation in secular activities. We think that exploring the ways that religious/spiritual development influences how youth engage with a variety of secular activities such as sports, education, arts, and gaming can provide an important window into the religious and spiritual lives of youth. For example, youth could be asked about how their religious beliefs and commitments have influenced or are influenced by their engagement with education, recreation, and other activities.

Wrestling with BIG questions. We have previously proposed that part of religious/spiritual development may involve wrestling with what we call the BIG questions (questions on Being, Intimacy, and God). We proposed that young people would be well served by thinking about and trying to find answers such existential questions (see Marks and Dollahite 2017, pp. 6-7) because such answers could help them make crucial life decisions that would have significant impact on their psychological and relational wellbeing across the lifespan. We posit that scholars could better understand positive religious/spiritual development if youth were asked, for example, if and how they believe their faith community helps them address core ontological questions as "Who am I?" and "What is my purpose in life?" and "What does God expect of me?" and "What is my mission in life?" Our own conversations with more than 80 religious youth, as well as hundreds of youth with whom we have worked in the youth programs in our own faith communities, indicate that many of them think about these questions and look to their faith for answers to these and many other BIG questions.

Conversion and disaffiliation. For decades, evidence has suggested that many older youth and young adults are more likely to report being less involved with institutional forms of religion (e.g., with congregations). Recent evidence indicates that religious institutions are losing more youth and getting fewer back. With the increasing trend toward less affiliation with religious institutions present among younger Americans, studies investigating why youth leave (disaffiliation), why they stay away, and why they return (reconversion) would be valuable. Studies could investigate the factors that lead to youth choosing to leave the faith they were raised in and, for those who do, what factors lead them to choose to return to that faith. Another important area of study would be how youth can become what clinicians call "transitional characters" or someone who dramatically changes the trajectory of intergenerational family patterns. For example, this would involve study of youth who come from a 
family with generations of religious involvement who decide to leave that faith or leave faith altogether or, conversely, to study youth who come from a family with a history of religious non-involvement who decide to embrace a serious commitment to a faith community.

Interfaith knowledge and experience. With increasing emphasis in schools, social media, and popular media on tolerance (and even embracing) of differences, including religious differences, it appears that more youth will have better knowledge of and meaningful experiences with those of other faiths or no faith. To what extent such interfaith knowledge and experience might influence positive religious/spiritual development would likely be a fruitful area of scholarly endeavor. For example, youth could be asked about how their understanding of other faiths or their experiences with members of other faiths has influenced their religious/spiritual development.

Impactful personal experiences. Perhaps one of the most significant areas of future investigation would be careful exploration of the potential role of impactful personal experiences. By impactful we mean experiences of such potency and meaning that they influence the direction of one's religious life. Those might be purely or mostly spiritual and religious experiences that could include transcendent experiences-sometimes called mystical experiences-where a youth reports some kind of encounter with God. They could be experiences that lead to conversion or disaffiliation, perceived answers to prayer, or otherwise feeling some kind of divine guidance, protection, or influence. We posit that the ways that exploration of impactful personal experiences of youth might influence religious/spiritual development is an exciting frontier of investigation.

Volunteerism and service. In addition to more vertical, that is human to divine, transcendent experiences, impactful personal experiences might also include deeply influential horizontal experiences where youth choose to serve or relate with others in the human family in ways that directly impact the youth themselves spiritually and/or religiously. Examples include missionary service, religious pilgrimages, and serving the underprivileged through outreach and/or humanitarian efforts whether directly faith-based or not. Various studies have shown that religion promotes, encourages, and facilitates service (Smith and Davidson 2014) including in youth and young adults (Smith and Denton 2005; Smith and Snell 2009). Exploring the ways that such service influences positive religious/spiritual development in youth would help us see if, how, and why working directly to do good in the world reflects, confirms or weakens religious identity and commitment. For example, youth could be asked whether they believe that their participation in a service project or mission trip has influenced them spiritually and, if so, how.

Religious rituals, ceremonies, and traditions. A number of studies indicate the power of rituals in shaping and reflecting religious identity and commitment (Chelladurai et al. 2018; Marks et al. 2018). We encourage investigation of the ways that personal, family, and community rituals, ceremonies, and traditions influence positive religious/spiritual development in youth. For example, youth could be asked about whether any religious ritual, ceremony, or tradition they have participated in has been meaningful or influenced their personal lives, and if so, how and why.

Mental illness. Studies have found that religiosity among teenagers often serves as a protective factor against mental illnesses (Wong et al. 2006), including depression (Pearce et al. 2003). Given the high and increasing rates of adolescent suicide, often accompanied by depression and anxiety, it would be important for scholars to study the relationship between mental illness and religious/spiritual development among adolescents. For example, youth could be asked about their own experiences with depression and anxiety and their religious lives. What are the most important aspects of religious belief, practice, and community that serve to help youth cope with depression and anxiety. Are there ways that some aspects of religious belief, practice, and community serve to increase depression and anxiety among youth? Are there ways that religious parents and leaders can help youth draw from religious sources to combat anxiety and depression?

Mindfulness and meditation. Mindfulness training is sweeping America. Meditation has been practiced by religious and nonreligious people across centuries and cultures. Many adults have been exposed to such training and practice and, presumably, find value in it. It would be interesting to 
know whether, among youth, various aspects of traditional religious practices such as prayer and meditation on sacred texts may serve a similar function. Since many nonreligious youth may find value in mindfulness and meditation it would be interesting to know to what extent and in what ways they consider these practices to be part of their spiritual lives.

Temperament and personality. There are a number of possible avenues of exploration on potential interactions between a person's temperament and personality and their religious/spiritual development. For example: Do more introverted youth prefer more solitary or small group approaches to spirituality? Do more impetuous youth make more dramatic religious choices and changes, for example, conversion from one faith to another? Are more intellectually oriented youth more likely to leave or join some faiths compared to others? Are persons with some personality types more likely to fully reject or embrace spirituality and religion?

Agency and personal choices. Most social science research focuses on the factors that are thought to influence, cause, or determine various human behaviors and attitudes. Less research acknowledges and accounts for human agency or choice. While there is value in looking for statistical correlations between variables, we believe that it is also important to ask youth (and adults) about choices they have made regarding their spiritual and religious lives and decisions. For example, youth could be asked about what personal choices they have made regarding their spiritual and religious commitments, beliefs, and practices. They can be asked to what extent their feel their religious lives have been determined for them or are a result of their own choices. They could be asked, if they had a chance to do it over, what different choices they wish they might have made—or what choices they think they will make when they are older.

Sexual orientation and experiences. Some studies indicate that sexual orientation can influence religiosity and spirituality. While there has been much written about how more traditional religions and more progressive faiths have addressed LGBTQ issues, there is room for scholarly study of how sexual orientation might intersect with positive religious/spiritual development. Since sexual behavior is regulated in most world faiths there has been much written about whether greater religiosity leads to sexual fidelity, sexual repression, sexual dysfunctions, and so forth. What has not been fully explored is how youth feel about the teachings regarding sexuality in their faiths and how sexual abstinence or involvement influences their personal spirituality. Sexual abuse and trauma have both received increasing scholarly attention and media attention (e.g., with the \#me too movement) and it would be timely to study connections between sexual abuse and trauma in youth and their religious/spiritual development.

The dark side of religion. This article has focused on positive religious/spiritual development and the salutary role that religious and spiritual involvement tend to have on both youth and their families. While these beneficial connections recur in the empirical literature, there is more to the story. Recent work, including our own, has emphasized that religion can both unite and divide (Kelley et al. 2019). Indeed, “Like a rope that can be used to helpfully bind in some situations—or annoyingly chafe and burn at other times - religious commitments that reportedly help unify many ... [families] may produce tension, irritation, and conflict [when] ... commitment to a faith is not shared" (Marks and Dollahite 2017, p. 59, italics in original). Further, religion can be profoundly helpful or deeply harmful depending on what individuals and families actually do as a result of their beliefs (Dollahite et al. 2018a; Marks and Dollahite 2017). Balanced scholarship must attend to constructive and destructive elements of religion for youth and their families.

Toward generative devotion. We hope to see research that explores the ideas of the theory of generative devotion (Dollahite et al. 2019b) as it applies to positive religious/spiritual development in youth. Given that generative devotion is about being religious in ways that attend to the wellbeing of family members, and given that generative devotion is other-oriented, responds to needs of persons, respects other's agency, and is relational in nature, we would appreciate seeing additional studies that address these issues. For example, youth could be asked to what extent they believe that their spiritual and religious lives prepare them to be caring and responsive to others and to relationships. Or they 
could be asked if and how they think their spiritual and religious commitments help them honor the choices and agency of others. The theory of generative devotion also highlights the problems caused by what we call destructive devotion (Dollahite et al. 2019b). Accordingly, research focused on how to nurture positive religious/spiritual development in youth while avoiding destructive expressions is also critical.

\section{Conclusions}

Religious and spiritual involvement tends to have a range of benefits for adolescents. Yet, selfish and destructive devotion can be harmful to youth — and children and adults. Therefore, scholarly investigation of the various ways that youth develop religiously and spiritually in ways that are positive for themselves and others will continue to be an important endeavor to better understand how to facilitate the wellbeing of future generations.

Author Contributions: Conceptualization, D.C.D. and L.D.M.; Writing-original draft, D.C.D. and L.D.M.

Funding: This research received no external funding.

Conflicts of Interest: The authors declare no conflict of interest.

\section{References}

Armet, Stephen. 2009. Religious socialization and identity formation of adolescents in high tension religions. Review of Religious Research 50: 277-97.

Bengtson, Vern L., Norella M. Putney, and Susan Harris. 2013. Families and Faith. New York: Oxford.

Benson, Peter L., Eugene C. Roehlkepartain, and Stacey P. Rude. 2003. Spiritual Development in Childhood and Adolescence: Toward a Field of Inquiry. Applied Developmental Science 7: 205-13. [CrossRef]

Boyatzis, Chris J., David C. Dollahite, and Loren D. Marks. 2006. The family as a context for religious and spiritual development in children and youth. In The Handbook of Spiritual Development in Childhood and Adolescence. Edited by Eugene C. Roehlkepartain, Pamela Ebstyne King, Linda M. Wagener and Peter L. Benson. Thousand Oaks: Sage, pp. 297-309.

Chelladurai, Joe M., David C. Dollahite, and Loren D. Marks. 2018. The family that prays together. Journal of Family Psychology 32: 849-59. [CrossRef] [PubMed]

Corbin, Juliet, and Anselm Strauss. 2008. Basics of Qualitative Research. Thousand Oaks: Sage.

Damon, William, and Anne Colby. 2013. Why a true account of human development requires exemplar research. In Exemplar Methods and Research. Edited by M. K. Matsuba, P. E. King and K. C. Bronk. San Francisco: Jossey-Bass, vol. 142, pp. 13-25. [CrossRef]

Dollahite, David C., and Loren D. Marks. 2018. Introduction to the special issue: Exploring strengths in American families of faith. Marriage and Family Review 54: 617-34. [CrossRef]

Dollahite, David C., and Jennifer Y. Thatcher. 2008. Talking about religion: How religious youth and parents discuss their faith. Journal of Adolescent Research 23: 611-41.

Dollahite, David C., Emily Layton, Howard M. Bahr, Anthony B. Walker, and Jennifer Y. Thatcher. 2009. Giving up something good for something better: Sacred sacrifices made by religious youth. Journal of Adolescent Research 24: 691-725. [CrossRef]

Dollahite, David C., Loren D. Marks, and Hilary Dalton. 2018a. Why religion helps and harms families. Journal of Family Theory and Review 10: 219-41. [CrossRef]

Dollahite, David C., Loren D. Marks, Taleah M. Kear, Brittany M. Lewis, and Megan L. Stokes. 2018b. Beyond the bucket list: Identity-centered religious calling, being, and action among parents. Psychology of Religion and Spirituality 10: 44-54. [CrossRef]

Dollahite, David C., and Loren D. Marks, eds. 2019. Strengths in Diverse Families of Faith: Exploring Religious Differences. New York: Routledge.

Dollahite, David C., Loren D. Marks, and Betsy Hughes Barrow. 2019a. Relational reconciliation processes in Christian, Jewish, and Muslim families. Family Relations. [CrossRef]

Dollahite, David C., Loren D. Marks, and Greg J. Wurm. 2019b. Generative devotion: A theory of sacred relational care in families of faith. Journal of Family Theory and Review 11: 429-448. [CrossRef] 
Dollahite, David C., Loren D. Marks, Kate P. Babcock, Betsy H. Barrow, and Andrew H. Rose. 2019c. Beyond religious rigidities. Religions 10: 111. [CrossRef]

Dowling, Elizabeth M., Steinunn Gestsdottir, Pamela M. Anderson, Alexander Von Eye, Jason Almerigi, and Richard M. Lerner. 2010. Structural relations among spirituality, religiosity, and thriving in adolescence. Applied Developmental Science 8: 7-16. [CrossRef]

Ebstyne King, Pamela, and James L. Furrow. 2008. Religion as a resource for positive youth development: Religion, social capital, and moral outcomes. Psychology of Religion and Spirituality S, 34-49. [CrossRef]

Handel, Gerald. 1996. Family worlds and qualitative family research. Marriage and Family Review 24: 335-48. [CrossRef]

Hardy, Sam A., David C. Dollahite, Natalie Johnson, and Justin B. Christensen. 2015. Adolescent motivations to engage in prosocial behaviors and abstain from health-risk behaviors: A self-determination theory approach. Journal of Personality 83: 479-90. [PubMed]

Hardy, S. A., D. C. Dollahite, and Chayce Baldwin. 2018. Parenting, religion, and moral development. In The Oxford Handbook of Parenting and Moral Development. Edited by Deborah Laible, Gustavo Carlo and Laura M. Padilla-Walker. New York: Oxford, forthcoming.

Hardy, Sam A., Janae M. Nelson, Joseph P. Moore, and Pamela Ebstyne King. 2019. Processes of religious and spiritual influence in adolescence: A systemic review of 30 years of research. Journal of Research on Adolescence 29: 254-75. [CrossRef] [PubMed]

James, Anthony G., and Mark A. Fine. 2015. Relations between youths' conceptions of spirituality and their developmental outcomes. Journal of Adolescence 43: 171-80. [PubMed]

James, Anthony, and Rose Marie Ward. 2019. Temporal relation between youths' perceived spirituality and indicators of positive development. Journal of Research on Adolescence 29: 345-56. [CrossRef] [PubMed]

James, Anthony G., Mark A. Fine, and Linda Jo Turner. 2012. An empirical examination of youths' perceptions of spirituality as an internal developmental asset during adolescence. Applied Developmental Science 16: 181-94. [CrossRef]

Jones, Robert P. 2016. The End of White Christian America. New York: Simon \& Schuster.

Kelley, Heather H., Loren D. Marks, and David C. Dollahite. 2019. Uniting and dividing influences of religion on marriage. Psychology of Religion and Spirituality. [CrossRef]

Kim-Spoon, Jungmeen, Gregory S. Longo, and Michael E. McCullough. 2012. Parent-adolescent relationship quality as a moderator for the influence of parents' religiousness on adolescents' religiousness and adjustment. Journal of Youth and Adolescence 41: 1576-87.

King, Pamela Ebstyne, and Chris J. Boyatzis. 2004. Exploring adolescent spiritual and religious/spiritual development. Applied Developmental Science 8: 2-6. [CrossRef]

Layton, Emily, David C. Dollahite, and Sam A. Hardy. 2011. Anchors of religious commitment in adolescents. Journal of Adolescent Research 26: 381-413.

Layton, Emily, Sam A. Hardy, and David C. Dollahite. 2012. Religious exploration among highly religious American adolescents. Identity 12: 157-84. [CrossRef]

Marks, Loren D., and David C. Dollahite. 2011. Mining the meanings from psychology of religion's correlation mountain. Psychology of Religion and Spirituality 3: 181-93.

Marks, Loren D., and David C. Dollahite. 2017. Religion and Families. New York: Routledge.

Marks, Loren D., and David C. Dollahite. 2018. Surmounting the empathy wall: Deep respect and holy envy in qualitative scholarship. Marriage and Family Review 54: 762-73. [CrossRef]

Marks, Loren, David C. Dollahite, and Jeffrey Dew. 2009. Enhancing cultural competence in financial counseling and planning. Journal of Financial Counseling and Planning 20: 13-26.

Marks, Loren D., Trevan G. Hatch, and David C. Dollahite. 2018. Sacred practices and family processes in a Jewish context. Family Process 57: 448-61. [CrossRef]

McMurdie, Carrolyn A., David C. Dollahite, and Sam A. Hardy. 2013. Adolescent and parent perceptions of the influence of religious belief and practice. Journal of Psychology and Christianity 32: 192-205.

Pearce, Michelle J., Todd D. Little, and John E. Perez. 2003. Religiousness and depressive symptoms among adolescents. Journal of Clinical Child \& Adolescent Psychology 32: 267-76.

Petts, Richard J. 2014. Family, religious attendance, and trajectories of psychological well-being among youth. Journal of Family Psychology 28: 759-68. [CrossRef] [PubMed] 
Pew Research Center. 2009. Faith in Flux. Washington, DC: Pew, Available online: http://www.pewforum.org/ 2009/04/27/faith-in-flux/ (accessed on 13 February 2019).

Pew Research Center. 2016. Why America's 'Nones' Left Religion Behind. Washington, DC: Pew, August, Available online: http://www.pewresearch.org/fact-tank/2016/08/24/why-americas-nones-left-religionbehind/ (accessed on 13 February 2019).

Roehlkepartain, Eugene C., Pamela Ebstyne King, Peter L. Benson, and Linda Wagener, eds. 2006. The Handbook of Spiritual Development in Childhood and Adolescence. Thousand Oaks: SAGE.

Salas-Wright, Christopher P., Michael G. Vaughn, and Brandy R. Maynard. 2014. Religiosity and violence among adolescents in the United States. Journal of Interpersonal Violence 29: 1178-200.

Smith, Christian. 2003. Theorizing religious effects among American Adolescents. Journal for the Scientific Study of Religion 42: 17-30. [CrossRef]

Smith, Christian, and Hilary Davidson. 2014. The Paradox of Generosity. New York: Oxford.

Smith, Christian, and Melina Lundquist Denton. 2005. Soul Searching. New York: Oxford.

Smith, Christian, and Patricia Snell. 2009. Souls in Transition. New York: Oxford.

Volling, Brenda L., Annette Mahoney, and Amy J. Rauer. 2009. Sanctification of parenting, moral socialization, and young children's conscience development. Journal of the Psychology of Religion 1: 53-68.

Wong, Y. Joel, Lynn Rew, and Kristina D. Slaikeu. 2006. A systematic review of recent research on adolescent religiosity/spirituality and mental health. Issues in Mental Health Nursing 27: 161-83. [CrossRef] [PubMed]

(C) 2019 by the authors. Licensee MDPI, Basel, Switzerland. This article is an open access article distributed under the terms and conditions of the Creative Commons Attribution (CC BY) license (http://creativecommons.org/licenses/by/4.0/). 